\title{
Assessment of physicochemical quality of water from springs in the Bittit area (EI Hajeb, Morocco)
}

\author{
Said Laafou ${ }^{1}$, Abdelaziz Abdallaoui ${ }^{1 *} \&$ Rachid Ben Aakame ${ }^{2}$ \\ ${ }^{I}$ (Moulay Ismail University, Faculty of Sciences, Department of Chemistry, Analytical Chemistry and \\ Environment Team, PO Box 11201, Zitoune, Meknes, Morocco) \\ 2 (National Institute of Hygiene, Department of Toxicology and Hydrology, Rabat, Morocco)
}

\begin{abstract}
Groundwater is a major source of water for drinking, agricultural, and industrial desires. The availability of water determines the location and activities of humans in an area and our growing population is placing great demands upon natural fresh water resources. However, they are sometimes exposed to various forms of pollution such as agricultural, industrial and residential. This work has an objective evaluation of physicochemical quality of water from springs in the region of Bittit, which is used in the supply of drinking water for a large population. The results obtained in this study show that the water studied has a conductivity that varies between $463 \mu \mathrm{s} / \mathrm{cm}$ and $734 \mu \mathrm{s} / \mathrm{cm}$. Nitrate concentrations varied between $16.17 \mathrm{mg} / \mathrm{l}$ and $17.72 \mathrm{mg} / \mathrm{l}$. Concentrations of major ions $\left(\mathrm{Ca}^{2+}, \mathrm{Mg}^{2+}, \mathrm{K}^{+}, \mathrm{Na}^{+}, \mathrm{SO}_{4}{ }^{2}, \ldots\right)$ as well as the values of the parameters $(\mathrm{pH}$, temperature, hardness, ...) do not exceed the Moroccan standards (NM 03.7.001, 2006) relating to drinking water.
\end{abstract}

Keywords: springs, physicochemical, quality, Bittit area

\section{INTRODUCTION}

Water and environmental protection are currently two major concerns for every country in the world, because water is an important factor for sustainable development. Currently, a large number of regions in Morocco have had a problem of water shortage. In Morocco, the groundwater is an important part of the hydraulic heritage of the country. Shortage of drinking water worldwide is becoming very acute nowadays [1].

Groundwater represents an important source of drinking water and its quality is currently threatened by a combination of over-abstraction and microbiological and chemical contamination [2]. Water intended for human consumption must not contain pathogens germs or harmful chemicals; because water contaminated with microorganisms is the cause of epidemics [3]. In addition, nitrate pollution of drinking water can cause methemoglobinemia or "blue baby" in infants and carcinogenic diseases in adults [4].

Meteorological events and pollution are few of the external factors which affect physicochemical parameters such as $\mathrm{pH}$, TDS and conductivity of the water. They have a major influence on biochemical reactions that occur within the water. Internal factors, on the other hand, include events which occur between and within bacterial and plankton populations in the body of water [5].

\section{MATERIALS AND METHODS}

\section{Presentation of the study area}

Bittit area is part of the province of El Hajeb. The province of El Hajeb is located in the plains of Saiis between $33^{\circ} 20^{\prime}$ and $34^{\circ} 0^{\prime}$ North altitude and between $5^{\circ} 10^{\prime}$ and $5^{\circ} 50^{\prime}$ West longitude and covers an area of $2210 \mathrm{~km}^{2}$. It is bounded on the north by the prefecture of Meknes, to the south by the province of Ifrane and Khenifra, to the east by the prefecture of Fez and Sefrou and to the west by the province of Khemisset (fig. 1).

\section{Climatology}

The province of El Hajeb has a continental climate, cold in winter and hot in summer, the temperature minimum (month of January) and maximum temperature (month of July) are respectively $-2{ }^{\circ} \mathrm{C}$ and $+40{ }^{\circ} \mathrm{C}$. The wet season lasts from October to May, while the dry season is from June to September. Annual precipitation shows a very erratic climate from one year to another. They generally range between $300 \mathrm{~mm}$ and $900 \mathrm{~mm}$ (fig.2). 


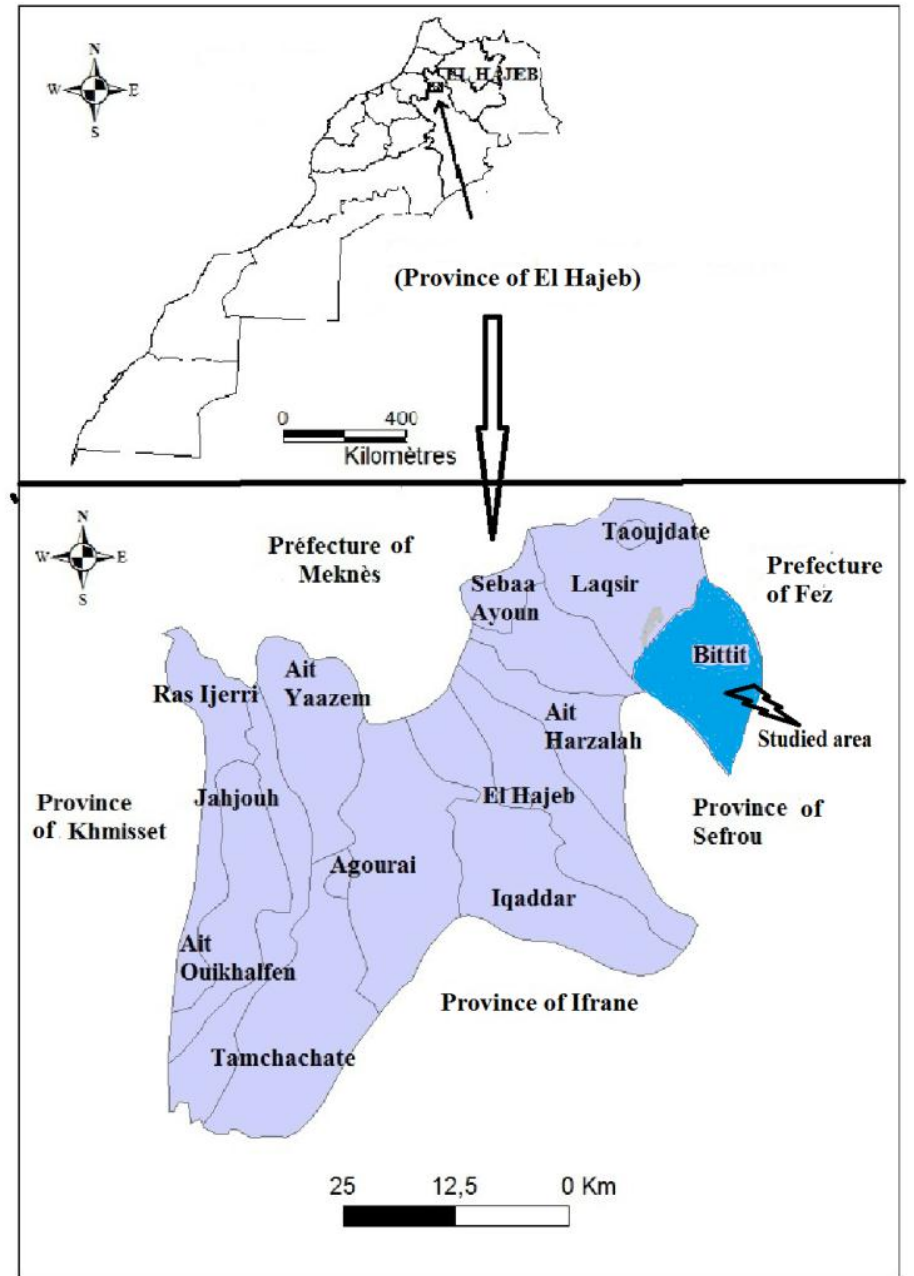

Fig.1: Location of studied area

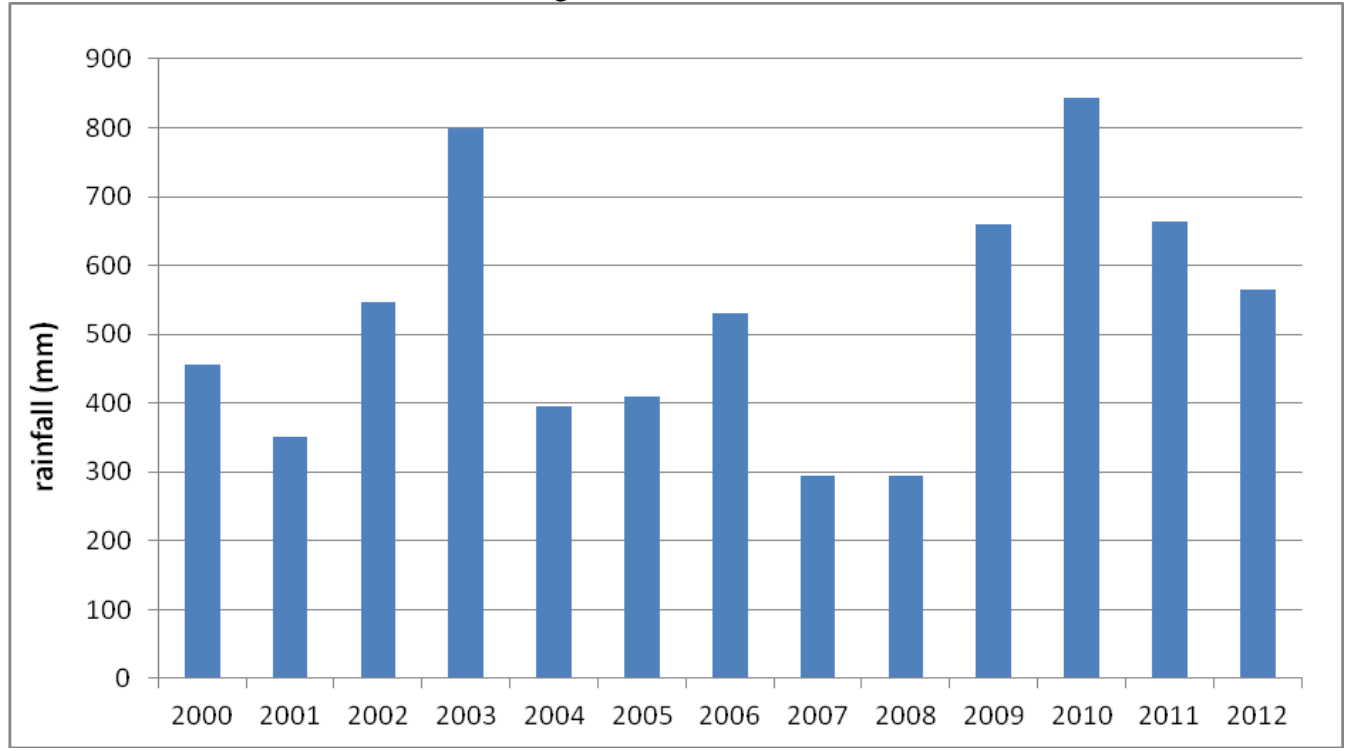

Fig.2: Annual evolution of rainfall between 2000 and 2012 in Bittit area

The springs surveyed are chosen according to the following criteria: accessibility and frequency of use by residents and passengers. They are located by the geographical coordinates and elevation using a GPS type (GARMIN GPSmap 62). Table 1 shows the names, geographical coordinate and elevation of the springs studied. 
Table 1: Name and geographical coordinates of springs explored

\begin{tabular}{|c|c|c|c|}
\hline Code & Source Name & Geographical coordinate & Elevation $(\mathbf{m})$ \\
\hline S1 & Aghbalou Agamgam & N 3345' 0.2” $\quad$ W 5'11'45.7" & 924 \\
\hline $\mathbf{S 2}$ & Ain Ribâa & N 334' $30.5^{\prime \prime} \quad$ W 5 $13^{\prime} 50.1 "$ & 878 \\
\hline S3 & Ain Sebaa 1 & N 334' $36.5^{\circ} "$ W 509'43.3" & 742 \\
\hline S4 & Ain Sebaa 2 & $\mathrm{~N} 33^{\circ} 47^{\prime} 32.1^{\prime \prime} \quad \mathrm{W} 5^{\circ} 09^{\prime} 46.7^{\prime \prime}$ & 755 \\
\hline S5 & Ain Lahnach & N 334' 9.8” $\quad$ W 5'12'45.2” & 849 \\
\hline S6 & Ain Bittit & N 334' 38.7” W $5^{\circ} 11^{\prime} 7.3^{\prime \prime}$ & 764 \\
\hline
\end{tabular}

\section{Sampling and physic chemical analyzes}

The samples were collected from all the stations at 11.00 am to 12.00 in the month of October 2012 for physicochemical examinations. The samples were collected in plastic bottles of two liters capacity without any air bubbles. Transportations of samples were kept in refrigerator maintained at $+4^{\circ} \mathrm{C}$ to hydrology laboratory at the National Institute of Hygiene (INH) in Rabat. Utmost care was taken during sampling to avoid any kind of contamination.

The analyses of various physicochemical parameters were carried out as per the method described by Jean Rodier (2009) [6]. The temperature, potential of hydrogen $(\mathrm{pH})$ and electrical conductivity were measured at the time of sample collection. $\mathrm{pH}$ was measured with Portable Field pH Meter, type (WTW pH 330i/SET), conductivity with Handheld Conductivity Meter, type (WTW cond 330i/SET). The temperature was measured by a thermometer built into the Conductivity Meter and the $\mathrm{pH}$ Meter. Nitrate $\left(\mathrm{NO}_{3}{ }^{-}\right)$, nitrite $\left(\mathrm{NO}_{2}{ }^{-}\right)$, ammonia nitrogen $\left(\mathrm{NH}_{4}{ }^{+}\right)$and sulphate $\left(\mathrm{SO}_{4}{ }^{2-}\right)$ are determined by a colorimetric method using a UV/visible spectrophotometer type (JASCO V-530). Total Hardness (TH), calcium $\left(\mathrm{Ca}^{2+}\right)$ and magnesium $\left(\mathrm{Mg}^{2+}\right)$ were determined by the volumetric method with EDTA (Ethylenediaminetetraacetic-acid). The oxidizability (organic materials: $\mathrm{OM}$ ) is determined by high temperature oxidation in acidic medium. Alkalinity total (AT) and bicarbonate $\left(\mathrm{HCO}_{3}{ }^{-}\right)$are analyzed by volumetric dosing with $0.1 \mathrm{~N} \mathrm{HCl}$. Sodium $\left(\mathrm{Na}^{+}\right)$and potassium $\left(\mathrm{K}^{+}\right)$are determined by excitation of the atoms by flame photometer type (AFP-100).

\section{RESULT AND DISCUSSION}

The values of physicochemical parameters of water analyzes for the six springs studied are shown in Table 2. Based on the results, temperature, $\mathrm{pH}$, conductivity, nitrates, nitrites, ammonia, sulfates, chlorides, magnesium and organic matter $(\mathrm{OM})$ recorded values below the standards recommended by the Ministry of health of Morocco[7] respectively $\left(25^{\circ} \mathrm{C}, 6.5\right.$ and $8.5 ; 2700 \mu \mathrm{s} / \mathrm{cm}, 50 \mathrm{mg} / 1,0.5 \mathrm{mg} / 1,0.5 \mathrm{mg} / \mathrm{l}, 400 \mathrm{mg} / 1,750$ $\mathrm{mg} / \mathrm{l}$ and $5 \mathrm{mg} / \mathrm{l}$ ). The mean levels of sodium and potassium are respectively about $14.58 \mathrm{mg} / \mathrm{l}$ and $0.83 \mathrm{mg} / \mathrm{l}$. Bicarbonates $\left(\mathrm{HCO}_{3}{ }^{-}\right)$register values between $323.3 \mathrm{mg} / \mathrm{l}$ and $439.1 \mathrm{mg} / 1$, respectively observed at the source S5 and S3. For nitrite and ammoniacal nitrogen, we recorded the absence of both pollutants in groundwater of studied area. OM values were in range of $0.76 \mathrm{mg} / \mathrm{l}$ to $1.28 \mathrm{mg} / \mathrm{l}$. Other parameters, they as follows:

\section{Temperature (T):}

Temperature is an important biologically significant factor, which plays an important role in the metabolic activities of the organism. The temperature was ranging from $15.00^{\circ} \mathrm{C}$ to $18.20^{\circ} \mathrm{C}$ during the study period. Lowest water temperature $\left(15^{\circ} \mathrm{C}\right)$ was observed in spring S5 and highest temperature $\left(18.2{ }^{\circ} \mathrm{C}\right)$ value was observed in spring S4.

\section{2. pH:}

$\mathrm{pH}$ is a term used universally to express the intensity of the acid or alkaline condition of a solution. Most of the water samples are slightly alkaline due to presence of carbonates and bicarbonates. $\mathrm{pH}$ of groundwater influenced by geology of catchment area and the buffering capacity of water [8]. The $\mathrm{pH}$ values of water samples varied between 7.01 to 7.48 and were found within the limit prescribed by WHO [9].

\section{Electrical Conductivity (EC) in $\mu \mathrm{s} / \mathrm{cm}$ :}

Electrical conductivity reflects the ability of an aqueous to conduct electrical current. It signifies the amount of total dissolved salts [10]. EC is an important parameter in assessing water quality for drinking and irrigation purposes. EC is used as an indicator and classification of salinity. High values of EC in ground water are due to high dissolved solids. Therefore high EC means high degree of salinity and an index of the amount of dissolved substances in water [11].EC values vary from $734 \mu \mathrm{s} / \mathrm{cm}$ to $463 \mu \mathrm{s} / \mathrm{cm}$. Normal groundwater has a range of 100 to $2000 \mu \mathrm{s} / \mathrm{cm}$ [12]. The values of electrical conductivity in all springs are within the study area fall within the WHO standard for electrical conductivity. 


\section{Chloride ( $\mathrm{Cl}^{-}$) in $\mathrm{mg} / \mathrm{l}$ :}

The chloride concentration serves as an indicator of pollution by sewage. People accustomed to higher chloride in water are subjected to laxative effects [13]. In the present analysis, chloride concentration was found in the range of $14.2 \mathrm{mg} / \mathrm{l}$ to $31.95 \mathrm{mg} / \mathrm{l}$. Spring S4 registered the highest observed chloride level at 31.95 . Yet, this was far below the recommended WHO chloride level in drinking water. This again implies that all the waters studied were all of satisfactory quality in terms of their chloride contents and that chloride does not contribute to problems of taste in some of the waters.

\section{Sulphate $\left(\mathrm{SO}_{4}{ }^{2-}\right)$ in $\mathrm{mg} / \mathrm{l}$ :}

The sulphate naturally present in water, very variable concentration (major in contact with gypsum or and other common minerals) [14]. Discharge of industrial wastes and domestic sewage tends to increase its concentration. For all the samples analyzed, the sulphate level was in the range of 0.16 to 8.9 to $\mathrm{mg} / \mathrm{l}$. S6 had the least sulphate level while S3 had the highest sulphate level. The mean sulphate level value for all analyzed samples was $3.42 \mathrm{mg} / \mathrm{L}$. This result also confirms the acceptability of this groundwater in terms of their sulphate contents.

\section{Total Hardness $(\mathrm{TH})$ in $\left({ }^{\circ} \mathrm{F}\right)$ :}

Hardness is the property of water which prevents the lather formation with soap and increases the boiling points of water. Hardness of water mainly depends upon the amount of calcium or magnesium salts or both. TH values for the six springs studied show no major difference from one spring to the other. They vary between $26.4^{\circ} \mathrm{F}$ and $35.8{ }^{\circ} \mathrm{F}$, respectively recorded at the springs S5 and S3. Based on these results, the groundwater in Bittit area are generally hard. This hardness is the result of limestone terrain crossed by water.

\section{Total Alkalinity $(\mathrm{TA})$ in $\left({ }^{\circ} \mathrm{F}\right)$ :}

Alkalinity of water is its capacity to neutralize a strong acid and it is normally due to the presence of bicarbonate, carbonate and hydroxide compound of calcium, sodium and potassium. Total Alkalinity (TA), this parameter is of no large difference from one spring to another in the studied area, it oscillates between $26^{\circ} \mathrm{F}$ and $35.5^{\circ} \mathrm{F}$; observed values are $27^{\circ} \mathrm{F}, 28.5^{\circ} \mathrm{F}, 35.5^{\circ} \mathrm{F}, 33^{\circ} \mathrm{F}, 26^{\circ} \mathrm{F}$ and $26.5^{\circ} \mathrm{F}$, respectively observed in S1, S2, S3, S4, S5 and S6.

\section{Calcium $\left(\mathrm{Ca}^{2+}\right)$ in $\mathrm{mg} / \mathrm{l}$ :}

Calcium is a soft gray alkaline earth metal which is directly related to hardness. Calcium concentration ranged between 44.88 to $80.97 \mathrm{mg} / \mathrm{l}$, respectively observed in springs S2 and S3. Mean value is $63.6 \mathrm{mg} / \mathrm{l}$.

Table 2: The various physicochemical parameters of water of springs in the Bittit area

\begin{tabular}{|c|c|c|c|c|c|c|}
\hline Springs & S1 & S2 & S3 & S4 & S5 & S6 \\
\hline $\mathbf{T}\left({ }^{\circ} \mathbf{C}\right)$ & 15.4 & 16.7 & 17,3 & 18.2 & 15.0 & $\begin{array}{l}15.9 \\
\end{array}$ \\
\hline pH & 7.10 & 7.14 & 7,01 & 7.19 & 7.48 & 7.17 \\
\hline $\mathrm{EC}(\mu \mathrm{s} / \mathrm{cm})$ & 537 & 459 & 734 & 679 & 463 & 536 \\
\hline TA $\left({ }^{\circ} \mathbf{F}\right)$ & 27 & 28.5 & 35.5 & 33 & 26 & 26.5 \\
\hline TH $\left({ }^{\circ} \mathbf{F}\right)$ & 30.0 & 31.6 & 35.8 & 34.8 & 26.4 & 32.0 \\
\hline $\mathrm{HCO}_{3}{ }^{-}(\mathrm{mg} / \mathrm{l})$ & 335.5 & 353.8 & 439.1 & 408.7 & 323.3 & 329.4 \\
\hline $\mathrm{Ca}^{2+}(\mathrm{mg} / \mathrm{l})$ & 62.52 & 44.88 & 80.97 & 75.37 & 56.11 & 61.72 \\
\hline $\mathrm{Mg}^{2+}(\mathrm{mg} / \mathrm{l})$ & 35.02 & 49.61 & 37.94 & 38.92 & 30.15 & 40.37 \\
\hline $\mathrm{SO}_{4}{ }^{2-}(\mathrm{mg} / \mathrm{l})$ & 0.95 & 2.80 & 8.90 & 7.19 & 0.5 & 0.16 \\
\hline $\mathrm{Cl}^{-}(\mathrm{mg} / \mathrm{l})$ & 14.20 & 21.30 & 24.85 & 31.95 & 14.20 & 14.20 \\
\hline $\mathrm{NO}_{3}^{-}(\mathrm{mg} / \mathrm{l})$ & 16.70 & 17.72 & 16.17 & 16.93 & 16.87 & 17.18 \\
\hline $\mathrm{NO}_{2}^{-}(\mathrm{mg} / \mathrm{l})$ & $<\mathrm{LD}^{*}$ & $<\mathrm{LD}^{*}$ & $<\mathrm{LD}^{*}$ & $<\mathrm{LD}^{*}$ & $<\mathrm{LD}^{*}$ & $<\mathrm{LD}^{*}$ \\
\hline $\mathrm{NH}_{4}{ }^{+}(\mathrm{mg} / \mathrm{l})$ & $<\mathrm{LD}^{*}$ & $<\mathrm{LD}^{*}$ & $<\mathrm{LD}^{*}$ & $<\mathrm{LD}^{*}$ & $<\mathrm{LD}^{*}$ & $<\mathrm{LD}^{*}$ \\
\hline $\mathrm{Na}^{+}(\mathrm{mg} / \mathrm{l})$ & 15 & 11 & 19 & 14 & 13 & 15 \\
\hline $\mathbf{K}^{+}(\mathbf{m g} / \mathbf{l})$ & 1.0 & 0.5 & 1.0 & 1.0 & 0.5 & 1.0 \\
\hline OM (mg/l) & 0.76 & 1.02 & 1.28 & 0,58 & 0.96 & 0.89 \\
\hline
\end{tabular}

* Less than the limit of detection. 


\section{Magnesium $\left(\mathrm{Mg}^{2+}\right)$ in $\mathrm{mg} / \mathrm{l}$ :}

This is one of the most abundant elements in nature and it is a significant member in water hardness, it gives an unpleasant taste to water [15]. Magnesium content in the investigated water samples was ranging from $30.15 \mathrm{mg} / \mathrm{l}$ to $49.61 \mathrm{mg} / \mathrm{l}$ to, with mean value $38.67 \mathrm{mg} / \mathrm{l}$.

\section{Nitrates $\left(\mathrm{NO}_{3}{ }^{-}\right)$in $\mathrm{mg} / \mathrm{l}$ :}

Nitrogen is a naturally occurring element that is essential for the life of plants and animals. Low levels of nitrogen (in the form of nitrate) are normal in groundwater and surface water. However, elevated nitrate caused by human activity is a pollutant in the water. Nitrate enters groundwater from many sources, including nitrogen-rich geologic deposits, wild-animal wastes, precipitation, septic system drainage, feedlot drainage, dairy and poultry production, municipal and industrial waste, and fertilizer [16]. Nitrate levels in the study area do not show large variations between different springs. Concentrations values of this parameter varied from $16.17 \mathrm{mg} / \mathrm{l}$ to $17.72 \mathrm{mg} / \mathrm{l}$ and found within the prescribed limit.

\section{CONCLUSION}

The assessment of water quality is an important factor to assess of pollution levels. This study revealed that the water in the studied area is suitable for drinking and other domestic purposes at the physicochemical level. The results were compared favourably with Moroccan standards. Periodical assessment of microbial analysis of the area studied should be carried out, as this would be helpful in early detection of any future degradation in order to fight against water-borne diseases.

\section{Acknowledgements}

The authors feel great pleasure in expressing their deep sense of gratitude and sincere thanks to Dr. A. El Abidi, Head of Department of Toxicology and Hydrology (INH) in Rabat, for providing the laboratory for testing the samples and for his continued support. We also thank our friends for their help and support in completing this research. We also thank Mr. Ousama Najim, a Professor at the American Language Center for his proofreading help.

\section{REFERENCES}

[1] A. Salem Mansour and I. Alshergawi Mohammed, Physico-chemical Evaluation of Drinking Water Quality in Alshati District of Libya, Journal Of Environmental Science, Toxicology And Food Technology, 2013, 46-51.

[2] F. J. Angulo, S. Tippen, D. J. Sharp, B. J. Payne, C. Collier, J. E. Hill, T. J. Barret, R. M. Clark, E. E. Geldreich, H. D. Donnel et D. L. Swerdlow, A community waterborne outbreak of salmonellosis and effectveness of a boil water order, American Journal of Public Health, 87 (4), (1997) 580-584.

[3] J. M. Balbus et M. A. Embrey, Risk Factors for Waterborne Enteric Infections, Current Opinion in Gastroenterology, 18 (1), 2002, 46-50.

[4] Landreau, Water pollution by nitrates, Water and Development, 2, 1990, 49-48.

[5] Ozaki, Y. Adachi, Y. Iwahori, and N. Ishii, Application of fuzzy theory to writer recognition of Chinese characters, International Journal of Modelling and Simulation, 18(2), 1998, 112-116.

[6] J. Rodier, The water analysis, (Paris, $9^{\text {th }}$ edition, 2009).

[7] Ministry of Health of Morocco, NM 03.7.001, Moroccan standard for the quality of water for human consumption (Official Bulletin No. 5404, 2006).

[8] W. J. Jt. Weber and W. Stun, Mechanism of hydrogen ion buffering in natural waters. J. Amer. Water Works Assn. 55, 1963, 1533 1538.

[9] World Health Organization, Guide lines for drinking water quality-I, (Recommendations. $2^{\text {nd }}$ Ed. Geneva WHO, 1993).

[10] Sudhir Dahiya and Amarjeet Kaur, physico chemical characteristics of underground water in rural areas of Tosham subdivisions, Bhiwani district, Haryana, J. Environ Poll., 6 (4), 281 (1999).

[11] C. H. Srinivas, C. Piska, M. S. Venkatesan, S.N. Rao and R. R. Reddy, Studies on groundwater quality of Hyderabad. Pollution Res. 19(2), 2000, 285.

[12] M.E. Offodile, Ground Water Study and Development in Nigeria (Mecon Geology and Eng. Services Ltd. 2002) 303-332.

[13] S. Dahiya and A. Kaur, physic chemical characteristics of underground water in rural areas of Tosham subdivisions, Bhiwani district, Haryana, J. Environ Poll., 6 (4),1999, 281.

[14] P. Queneau, and J. Hubert, Place of mineral water in the diet. Report of the National Academy of Medicine. French Society of Medical Hydrology and Climatology, France, 2009, Pp. 175-220.

[15] J. Rodier, The water analysis "natural water, waste water, sea water" (Paris: Bordas, 1984).

[16] R.F. Follett, D.R. Keeney, and R.M. Cruse, Managing Nitrogen for Groundwater Quality and Farm Profitability (Soil Science Society of America, Inc. 1991). 